\title{
Land Requirements, Feedstock Haul Distance, and Expected Profit Response to Land Use Restrictions for Switchgrass Production
}

\begin{abstract}
Energy crop production has been proposed for land of poor quality to avoid competition with food production and negative indirect land use consequences. The objective of this study was to determine the land area requirements, biomass transportation distance, and expected profit consequences of restricting switchgrass biomass production, for use as biofuel feedstock, to marginal land relative to unrestricted land use. The USA soils capability classification system was used to differentiate between high quality land and land of marginal quality. Fifty years of historical weather data were used in combination with a biophysical simulation model to estimate switchgrass biomass yield distributions for land of different quality for counties in the case study region. A mathematical programming model was designed and solved to determine the economic consequences. For the levels of biofuel price considered $(\$ 0.50, \$ 0.75$ and $\$ 1.00$ /L), and a 262.5 M L/year biorefinery modeled, restricting land use to marginally productive capability Class IV soils, increases the quantity of land optimally leased by 42 to $52 \%$; increases biomass trucking total transportation distance by 115 to $116 \%$; and reduces the expected net returns by $\$ 11$ to $\$ 15 \mathrm{M} /$ year compared to when land use is unrestricted. In the absence of government restrictions, for-profit companies are not likely to limit energy crop production to land of marginal quality.
\end{abstract}

Keywords: biofuel; biorefinery; cellulosic ethanol; EPIC; land capability class; marginal land; switchgrass

JEL classifications: C60, Q42, Q24 


\section{Introduction}

The production of energy crops such as switchgrass (Panicum virgatum L.) in the USA was envisioned as a way to reduce the cost of government funded set aside and land retirement programs that had been implemented to reduce what had been described as an excess capacity problem. It was assumed that most of the land in these programs was of lower quality and that it could be put to productive use growing biomass crops that could then be converted to valuable products. For example, McLaughlin et al. wrote “...the rationale for developing lignocellulosic crops for energy is that ...poorer quality land can be used for these crops, thereby avoiding competition with food production on better quality land...” (McLaughlin et al., 1999, p. 293). In which case, the indirect land use issue, confronted when highly productive land is used to produce grain for conversion to ethanol resulting in land elsewhere on the globe converted from grassland to grain production, as described by Searchinger et al. (2008) and others (Leal et al., 2013; Winchester and Reilly, 2015; Wise et al., 2014, 2015), would not be an issue.

Searchinger et al. (2008) reported that “...biofuels from switchgrass, if grown on USA corn lands, increase (greenhouse gas) emissions by 50\%...”. Leal et al. (2013) found that bioenergy crop production could result in significant greenhouse gas emissions. Wise et al. (2014) also concluded that dedicated energy crop production would result in land use changes with increased greenhouse gas emissions. Winchester et al. (2015) reported that meeting USA Federal Aviation Administration targets for renewable jet fuel would also result in increased greenhouse gas emissions. However, Bhardwaj et al. (2011) and Dauber et al. (2012) reported that bioenergy crops could provide environmental benefits if grown on less productive land. Dodder et al. (2015) reported that a hypothetical energy portfolio that includes cellulosic biofuels would result in less greenhouse gas emissions and lower food prices. Djomo et al. (2015) studied 
40 potential bioenergy production systems and found that the technologies have the potential to reduce greenhouse gas emissions by 8 to $114 \%$ relative to fossil fuels even with the inclusion of the direct and indirect land use changes.

A number of other studies have concluded, or assumed, that since millions of hectares (ha) of marginal land exist, much of it could be converted relatively easily from current use to the production of switchgrass (Perlack et al., 2005; Liu et al., 2011; Gelfand et al., 2013). For example, in a highly aggregated study, Perlack et al. (2005) estimated that more than 20 million USA ha of low quality land could be converted to biomass production with minimal effects on food, feed, and fiber production. If the land is marginal and not currently used intensively to produce food, feed, and fiber crops, it follows that conversion to switchgrass would not impact land use elsewhere and hence negate concern regarding the environmental consequences of indirect land use. However, prior to completely dismissing the indirect land use issue for dedicated energy crops such as switchgrass grown on marginal land, several issues remain to be resolved.

First, there is no universally accepted definition of marginal land (Richards et al., 2014). Second, in the USA and many other countries, most land suitable for switchgrass production is privately owned. Private owners have to have an incentive to establish switchgrass on their land. Third, while government incentives may be in place and used, in the USA, the construction of a switchgrass biomass to biofuel biorefinery requires an investor, or group of investors, to provide the capital necessary to build a plant. Prudent investors would require a business plan for providing a daily flow of biomass throughout the year for the expected life of the biorefinery. Fourth, switchgrass yields are variable. A planted land area may produce more biomass than can be processed in some years and insufficient biomass in others. Given the expected yield 
variability across years, determining the optimal quantity of land to bid from current use and convert to switchgrass is not a trivial matter. Fifth, restricting switchgrass production to marginal land will have economic consequences. Land use restrictions may reduce the profit potential and inhibit investment in cellulosic biorefineries. Information regarding the economic consequences of restricting land use to that of marginal productivity relative to enabling switchgrass production on high quality as well as marginal land is limited.

The objective of this study is to determine the land area requirements, biomass transportation distance, and expected profit consequences of restricting switchgrass biomass production, for use as biofuel feedstock, to marginal land relative to unrestricted land use. To achieve the objective, a working definition of marginal land is presented. Fifty years of historical weather data are used in combination with a biophysical simulation model to estimate switchgrass biomass yield distributions for land of different quality for counties in a case study region. A mathematical programming model is designed and solved to determine the economic consequences.

\section{Soil Classification}

In the USA, soils are classified into eight soil capability classes (Norton, 1939). This classification system may be used to provide a definition of marginal land. Classes V-VIII have limitations impractical to remedy that restrict their use to range, forestland, wildlife, and/or esthetic purposes. Class I soils have slight, and Class II soils have moderate limitations for crop production. Thus, Class I and II soils could be used to produce switchgrass but they are clearly not marginal. Class III soils have severe limitations that reduce the choice of plants and/or require special conservation practices. Class III soils could be considered as marginal. Class IV soils have very severe limitations that restrict the choice of plants and/or require very careful 
management. Class IV soils are clearly marginal relative to Classes I and II. Thus, for purposes of determining the consequences of restricting crop production for biorefinery feedstock to marginal USA land, either Class IV, or both Classes III and IV, could be defined as marginal.

\section{Modeling Framework}

The modeling effort is based on the assumption that an investor or group of investors would develop a business plan and secure the financing to construct a biorefinery designed to use switchgrass biomass exclusively. For a given biorefinery technology, differences in cost to produce biofuel across locations could largely be attributed to differences in cost of providing a flow of feedstock throughout the year. Given the cost to transport biomass, investors could be expected to select a supply region for a biorefinery location based on expectations regarding the cost to provide a continuous flow of the required quantity of feedstock.

A case study region was identified based on findings of a regulatory impact analysis conducted by the USA Environmental Protection Agency (2010). The EPA (2010) estimated potential feedstocks and biorefinery locations for fulfilling the 2022 cellulosic ethanol mandates included in the USA Energy Independence and Security Act (EISA). In the assessment projections, only $6 \%$ of the cellulosic ethanol feedstock requirements were projected to be met by switchgrass. The EPA projected that $85 \%$ of the switchgrass could be produced and processed in the state of Oklahoma.

Seven of the nine USA switchgrass biorefinery locations identified by EPA (2010) were in Oklahoma. For the present case study, a biorefinery siting was chosen near Okemah, in Okfuskee County, the geographical center of three of the seven Oklahoma locations identified by EPA (EPA, 2010; Debnath et al. 2014; 2015). A $150 \mathrm{~km}$ radius around the biorefinery location is 
used as the potential feedstock supply shed of the biorefinery encompassing 30 Oklahoma counties (Figure 1).

An economically efficient switchgrass biomass to biofuel production system would require coordination of feedstock production and transportation with processing. The biorefinery could engage in production contracts with farmers (Epplin et al., 2007). Alternatively, the biorefinery could vertically integrate by acquiring control of a sufficient quantity of land with long-term leases such that the expected annual yield on the leased area would be sufficient to fulfil expected annual biorefinery feedstock requirements. Other options such as a closedmembership producer cooperative could be implemented (Katz and Boland, 2002; Jensen et al., 2011). In either case, prior to investing, prudent investors could be expected to require that use rights would be secured to a sufficient land area. Further, the expected annual biomass yield on the secured land would be available for delivery to fulfil expected annual biorefinery feedstock requirements at or below the expected cost estimate described in the business plan.

Based on experience with the USA Conservation Reserve Program (CRP), Oklahoma land owners are willing to engage in long term contracts that provide an annual lease payment (Osborn et al., 2009). This history suggests that at some annual rental rate, land could be bid from existing use (Okwo and Thomas, 2014). A company could enter into long-term leases with landowners and establish stands of switchgrass. Long-term land leases would facilitate coordination of switchgrass biomass production and transportation logistics required to provide an efficient flow of feedstock throughout the year. If the annual feedstock requirements of the biorefinery and annual switchgrass yield were known with certainty, it would be straightforward to determine the quantity of land to lease. However, switchgrass biomass yields vary from yearto-year. In years with unfavorable switchgrass production weather, yields in the feedstock supply 
shed of the biorefinery may be low, and if too few hectares are leased, production from the leased land may be insufficient to meet the needs of the biorefinery. In other years, more biomass may be produced on the leased land than can be processed. However, in every year, payments must be made for all land leased.

Conceptually, the expected objective of the investors would be to maximize expected net returns or to maximize the return on their investment. Based on this conceptual framework, the land area selected, leased, and seeded to switchgrass, would be determined and fixed in year zero, simultaneously with construction of the biorefinery. In year one and subsequent years, biomass production on the fixed land area would vary depending on environmental conditions. Thus, a nested objective would be to determine the location, quality, and quantity of land to lease.

Two mathematical programming models that integrate both spatial (among counties and among land classes) and temporal (among years) switchgrass yield variability are developed. The first model does not envision storage across feedstock production seasons. It is designed to maximize expected net returns for the life of the biorefinery. The model solution produces an estimate of the optimal quantity, quality, and location of land to lease. An explicit feature of the model is that it enables shutting down the biorefinery when switchgrass yields are low, if it is economically optimal to do so, and leaving excess biomass unharvested in years when yields across the leased area exceed processing capacity. The second model enhances the first by enabling interyear storage at a given storage cost and accounts for expected interyear storage losses. Both models are presented and solved with switchgrass biomass yield data simulated from 50 years of weather data for each of the four land classes for each of 30 counties in the case 
study region. Solutions provided by both models are used to determine the economic consequences of restricting switchgrass production to marginal land.

\subsection{Model 1: No interyear storage}

A biorefinery with a processing capacity of 2,000 $\mathrm{Mg}$ of feedstock per day is considered. The biorefinery is expected to have a nameplate capacity to operate 350 days in a given year with an annual feedstock requirement of $700,000 \mathrm{Mg}$. In model 1 the objective is to maximize the annual expected net returns while allowing for some idle days when it is economical to do so in years of insufficient feedstock production. The model is designed to be consistent with the conceptual framework such that the land area selected, leased, and seeded to switchgrass, would be determined and fixed in year zero. In year one and subsequent years, biomass production from the fixed land area would vary depending on environmental conditions. The yields are different in each of the 50 states of nature for each county and each land class. To capture the consequences of historical weather cycles of both the year-to-year and within-year yield variability, the temporal order is maintained. In some states of nature, the area selected will produce less biomass than the biorefinery can process. For other states of nature, the land area selected will produce more biomass than can be processed. The objective function is specified as follows:

$$
\begin{aligned}
\max _{A P_{t}, X L_{c l}, X R_{t c l}, A T_{t c l}} E(N R)= & \theta \rho\left(\sum_{t=1}^{T} A P_{t}\right) / T-\sum_{c=1}^{C} \sum_{l=1}^{L} \lambda_{c l} X L_{c l}-\alpha\left(\sum_{t=1}^{T} \sum_{c=1}^{C} \sum_{l=1}^{L} X R_{t c l}\right) / T-\left(\sum_{t=1}^{T} \sum_{c=1}^{C} \sum_{l=1}^{L} \gamma_{c l} A T_{t c l}\right) / T \\
& -\delta\left(\sum_{t=1}^{T} A P_{t}\right) / T-O P C-A N F C
\end{aligned}
$$

where $E(N R)$ are the annual expected net returns to be maximized, $t$ is year (year 1 to year 50 ); $c$ is the county $(1,2, \ldots, 30), l$ is the land class (Class I, II, III, and IV); $A P_{t}$ is the quantity of biomass processed in year $t(\mathrm{Mg}) ; \theta$ is the price of biofuel $(\$ / \mathrm{L}) ; \rho$ is the bioconversion rate 
$(\mathrm{L} / \mathrm{Mg}) ; \lambda_{c l}$ is the production cost including amortized switchgrass establishment cost, land rent, switchgrass stand maintenance fertilizer and mowing costs in county $c$ for land class $l(\$ / \mathrm{ha})$; $X L_{c l}$ is land leased from land class $l$, in county $c$ for the life time of the project (ha); $\alpha$ is the raking cost (\$/ha); $X R_{t c l}$ is the quantity of class $l$ land raked in year $t$, in county $c$ (ha); $\gamma_{c l}$ is the biomass baling, stacking, and transportation cost from the centroid of land class $l$ in county $c$ to the biorefinery $(\$ / \mathrm{Mg}) ; A T_{t c l}$ is the quantity of biomass baled and transported in year $t$ from land class $l$ in county $c$ to the biorefinery $(\mathrm{Mg}) ; \delta$ is the variable plant operation and maintenance cost that depends on the quantity of biomass processed $(\$ / \mathrm{Mg}) ; O P C$ is the annual fixed plant operation and maintenance cost $(\$) ; A N F C$ is the annualized cost of the initial biorefinery investment (\$).

Equation (1) is optimized subject to the following constraints:

$$
X L_{c l} \leq \bar{X}_{c l} \quad \forall c, l
$$

Equation (2) restricts the quantity of land of class $l$ leased in county $c$ to not exceed the total land available from that land class in county $c$.

$$
X R_{t c l} \leq X L_{c l} \quad \forall t, c, l
$$

In equation (3) the land raked from land class $l$, in each year $t$, in each county $c$, cannot exceed the land of class $l$ leased in the corresponding county.

$$
A P_{t} \leq \Psi \quad \forall t
$$

Equation (4) recognizes that the quantity of biomass processed may be less than the plant processing capacity $(\Psi)$ during the years of insufficient feedstock production.

$$
A T_{t c l} \leq \eta_{t c l} X L_{c l} \forall t, c, l
$$


In equation (5) the quantity of biomass baled and transported from each county $c$, on land class $l$, in year $t$, cannot exceed the biomass produced in county $c$ on land class $l . \eta_{t c l}$ is the annual switchgrass biomass yield in county $c$, on land class $l$, in year $t$.

$$
A P_{t} \leq \sum_{c=1}^{C} \sum_{l=1}^{L} A T_{t c l} \quad \forall t
$$

The quantity of biomass processed in each year $t$ cannot exceed the quantity transported to the processing plant in equation (6).

$$
X L_{c l}, A P_{t}, A T_{t c l}, X R_{t c l} \geq 0
$$

Equation (7) restricts the choice variables to be nonnegative.

\subsection{Model 2: Facilitating interyear storage}

Model 2 enhances model 1 by allowing interyear storage. The objective is:

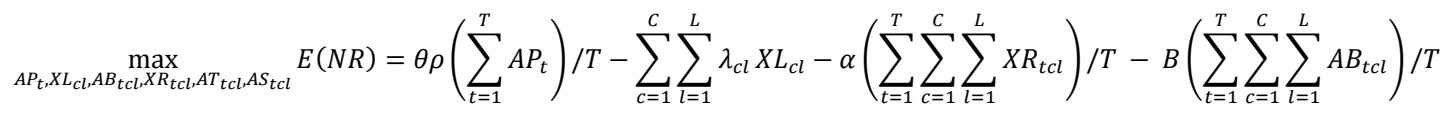

$$
\begin{aligned}
& -\left(\sum_{t=1}^{T} \sum_{c=1}^{C} \sum_{l=1}^{L} \tau_{c l} A T_{t c l}\right) / T-S\left(\sum_{t=1}^{T} \sum_{c=1}^{C} \sum_{l=1}^{L} A S_{t c l}\right) / T-\delta\left(\sum_{t=1}^{T} A P_{t}\right) / T-O P C-A N F C
\end{aligned}
$$

where $B$ is the baling and stacking cost $(\$ / \mathrm{Mg}) ; A B_{t c l}$ is the quantity of biomass baled on land class $l$ in year $t$ and in county $c(\mathrm{Mg}) ; \tau_{c l}$ is the biomass transportation cost from the centroid of land class $l$ in county $c$ to the biorefinery plant location $(\$ / \mathrm{Mg})\left(\gamma_{c l}\right.$ in model 1 is the sum of $B$ and $\tau_{c l}$ in model 2); $A T_{t c l}$ is the quantity of biomass transported in year $t$ from land class $l$ in county $c$ to the biorefinery $(\mathrm{Mg}), s$ is the switchgrass biomass interyear storage cost $(\$ / \mathrm{Mg} / \mathrm{year})$, $A S_{t c l}$ is the quantity of biomass $(\mathrm{Mg})$ stored in county $c$ from land class $l$ in year $t$ (interyear storage is assumed to be in production fields with access to all weather roads), the other variables and parameters are as defined in model 1.

In addition to the constraints in model 1 , model 2 includes additional constraints: 


$$
A S_{t+1 c l}=A B_{t c l}+A S_{t c l}-A T_{t c l} \quad \forall t, c, l
$$

In (9), the quantity of biomass in interyear storage for year $t+l$ in county $c$, and on land class $l$, is equal to the biomass baled in year $t$, from the same county and same land class plus the quantity in storage in year $t$, minus the quantity transported to the biorefinery.

$$
A S_{t c l} \leq A B_{t c l} \quad \forall t, c, l
$$

The biomass quantity stored during year $t$, in county $c$, and land Class $l$, cannot exceed the biomass baled.

$$
\text { ASuse }_{t c l}=(1-\emptyset) A S_{t c l} \forall t, c, l
$$

The usable biomass quantity from storage is equal to the quantity stored minus the storage loss. $\varnothing$ is the rate of storage loss (\% per year).

$$
A B_{t c l}, A T_{t c l}, A S_{t c l}, A S u s e_{t c l} \geq 0
$$

Equation (12) imposes the nonnegativity of the decision variables. In both models the set of land classes, $l$, collapses to one element for the scenario with land Class IV alone.

Collectively, the equations can be solved to identify the land for leasing that maximizes the annual expected net returns.

\section{Data}

\subsection{Transportation and land rental costs}

Spatial soil data from the USDA SSURGO data base (USDA NRCS, 2014) are used to determine the land area for land Classes I-IV in each of the 30 counties. Additionally, it is assumed that no more than $20 \%$ of the total land in each land class can be bid from current uses for switchgrass production. Several studies have been conducted to determine farmers and landowners willingness to convert from current land use activities to the production of switchgrass and other feedstocks (Jensen et al., 2007; Caldas et al., 2014; Skevas et al., 2016). 
These studies have found that many landowners are not interested in converting from existing land use activities to the production of switchgrass at existing land rental rates. Based on these findings, it is assumed that the land rental rates budgeted would be sufficient to obtain leases for $20 \%$ of the land.

The distance between the centroid of each land class and the potential biorefinery location near Okemah, Oklahoma, was determined using the geographical coordinates (latitude and longitude) of the two points. Transportation costs from the centroid of each land class in each county to the biorefinery are calculated using a modified version of a biomass transportation cost as a function of distance framework presented by Wang (2009).

The land rental cost for each land class in each county is estimated using the 2013 revealed CRP rental rates reported by the USDA, FSA (2014). The revealed CRP rental rates are adjusted using the expected wheat grain yield on each land class as reported in the USDA NRCS SSURGO data base (USDA NRCS, 2014) because wheat is the predominant crop within the case study region. By this measure, the wheat yield is used as a measure of land productivity for each land class in each county.

The average SSURGO wheat yield across the 30 counties in the case study region is 2.32 $2.11,1.63$, and $1.31 \mathrm{Mg} / \mathrm{ha}$ for Class I, II, III, and IV, respectively. Based on the USDA wheat production cost estimates (USDA, ERS, 2015) for 2012 and 2013, a yield of $2.11 \mathrm{Mg} / \mathrm{ha}$ would have been required to cover production costs for wheat produced in the region. Given the expected wheat yields as reported in the USDA SSURGO data base (USDA NRCS, 2014), the expected returns from growing wheat on Class III and IV lands in the region is negative. The negative expected returns from crop production are consistent with the vast majority of Class III and IV lands in the region being used for pasture. Based on average productivity differences 
among land classes, the average estimated rental costs, based on the revealed CRP rates for Classes II, III and IV are $89 \%, 67 \%$ and $55 \%$ of those of Class I, respectively.

\subsection{Switchgrass biomass yield distributions}

Historical switchgrass yield data are not available for each land class and county. Soils data were obtained from the USDA SSURGO soil datamart (USDA NRCS, 2014). Weather data, including solar radiation, maximum temperature, minimum temperature, relative humidity, wind velocity, and daily precipitation were gathered from the Oklahoma Mesonet (Oklahoma Climatological Survey, 2014) and the National Oceanic and Atmospheric Administration (2014). The soils and weather data were used in combination with the Environmental Policy Integrated Climate (EPIC) model to simulate historical switchgrass yields (Williams et al., 1984; Egbendewe-Mondzozo, 2011; Debnath et al., 2014; 2015).

The EPIC model was calibrated and validated with observed yields from three field experiments conducted at sites in the study region with one post-frost harvest per year (Fuentes and Taliaferro, 2002; Haque et al., 2009). Hence, the simulated yields follow from the assumption that switchgrass is harvested once per year after frost when the plant is assumed to be in a dormant stage. This approach ignores harvest timing issues and assumes that the harvestable yield is the same across all harvest months in the year. That is, for a given soil class in a specific county the harvestable yield from a November harvest is assumed to be the same as the harvestable yield from a January harvest. Further, in the harvest year, storage losses are assumed to be zero. For example, the quantity of dry matter available for processing from material harvested in November from a given soil class in a specific county is assumed to be the same as if immediately transported and processed in November, or if placed in field storage and transported and processed in March. Prior studies of just-in-time feedstock harvest and delivery 
systems have found that cost to deliver feedstock depends on the length of the harvest window, number of days suitable for harvesting, and differences in harvestable yield per month (Griffith et al., 2014; Haque et al., 2014; Zhang et al., 2013). Failure to account for these within year differences is a limitation of the current study.

The EPIC model was used to simulate switchgrass yields $\left(\eta_{t c l}\right.$ in equation (5)) for each of the four land classes, for each of 50 years of weather data (1962-2011), for each of 30 Oklahoma counties. The simulated annual yields are ordered based on the historical weather data series. On average the simulated yield on land Class II, III, and IV are 93\%, 77\%, and 59\% of the Class I simulated yield, respectively.

\subsection{Biorefinery data}

The 2,000 Mg per day biorefinery is assumed to process only switchgrass biomass with a biochemical conversion system using enzymatic hydrolysis. The projected biorefinery initial investment cost is estimated at $\$ 220 \mathrm{M}$ for a project life of 20 years (USA EPA, 2010). The total investment cost is amortized over the 20 -year expected project life with a discount rate at $6.5 \%$ to calculate the annualized investment cost (ANFC in equations (1) and (8)). The biomass to biofuel conversion rate ( $\rho$ in equations (1) and (8)) is assumed to be $375 \mathrm{~L} / \mathrm{Mg}$ (USA EPA, 2010). The base biofuel price ( $\theta$ in equations (1) and (8)) is set at $\$ 0.50 / \mathrm{L}$. Assuming the biofuel is ethanol, this is roughly equivalent to a crude oil price of $\$ 80 /$ barrel as projected by the USA EIA (2015) for 2022. The models are also solved with ethanol prices of $\$ 0.75 / \mathrm{L}$ and $\$ 1.00 / \mathrm{L}$, equivalent to crude oil prices, based on energy equivalence, of $\$ 131$ and $\$ 182 /$ barrel, respectively.

The annual operation and maintenance cost was estimated at \$57 M (USA EPA, 2010). The annual variable operation and maintenance cost ( $\delta$ in equations (1) and (8)) including 
enzyme cost, enzyme nutrients cost, other raw material cost, and waste disposal cost is $\$ 9 \mathrm{M}$, which is equivalent to $\$ 12.85 / \mathrm{Mg}$ of feedstock processed. The fixed operation and maintenance cost ( $O P C$ in equations (1) and (8)) is $\$ 48 \mathrm{M} /$ year. Since the feedstock production, harvest, and transportation costs are endogenous, the biomass procurement cost as estimated by EPA (US EPA, 2010) is not included in the operation and maintenance cost parameter.

\subsection{Interyear storage cost and storage loss}

Several studies have estimated region specific storage loss and storage cost. For the case study region, switchgrass harvest can extend from July through March of the following calendar year (Haque and Epplin, 2012). Over these nine months, it is assumed that switchgrass can be harvested and delivered to a biorefinery just-in-time, requiring minimal intrayear storage, the estimated cost of which is assumed to be non-significant in model 1 . However, based on our conceptual framework, interyear storage is incorporated in model 2 necessitating estimates for cost parameter $s$ in equation (8) and interyear storage loss parameter $\emptyset$ in equation (11). Based on estimates from previous studies, model 2 is solved for a storage loss estimate of $15 \%$ /year and for three levels of storage cost, $\$ 6, \$ 12$, and $\$ 18 \mathrm{Mg} /$ year (Larson et al., 2010; Sanderson et al., 1997; Turhollow et al., 2009; Cundiff and Marsh, 1996).

Bale and truck capacity estimates were synthesized from several sources (Wang, 2009; Larson et al., 2010; Turhollow and Epplin, 2010). The biomass is assumed to be harvested as $1.22 \mathrm{~m}$ wide by $1.83 \mathrm{~m}$ diameter round bales with an average bale weight of $540 \mathrm{~kg}$ dry matter. A class eight truck with day cab and a $16 \mathrm{~m}$ flatbed trailer is assumed to be used to transport the bales from fields to the biorefinery. It is assumed that two rows of eight bales could be placed on the trailer and two rows of seven bales could be placed on top of the bottom row enabling an average load of $16 \mathrm{Mg}$. 


\section{Results}

\subsection{Model 1: Optimal land lease with no interyear storage}

For the levels of biofuel price considered ( $\$ 0.50, \$ 0.75$ and $\$ 1.00 / \mathrm{L})$, restricting land use to Class IV increases the quantity of land optimally leased by 42 to $52 \%$ (Table 1); increases biomass trucking total transportation distance by 115 to $116 \%$; and reduces the expected net returns by $\$ 11$ to $\$ 15 \mathrm{M} / \mathrm{year}$ for the $262.5 \mathrm{M} \mathrm{L} /$ year nameplate capacity biorefinery compared to when land use is unrestricted.

If land use is restricted to Class IV, for an ethanol price of $\$ 0.50 / \mathrm{L}$, it is economically optimal to lease and establish switchgrass on 73,856 ha (Table 1 ). The average annual quantity of biomass transported to the $700,000 \mathrm{Mg}$ nameplate capacity biorefinery is $683,797 \mathrm{Mg}$. The feedstock production and transportation cost is $\$ 73 / \mathrm{Mg}$ with average expected net returns of $\$ 2.80 \mathrm{M} /$ year (Table 1). The base assumption is that 15 days/year would be required for maintenance. If the selected 73,856 ha are leased, the biorefinery would be shut down for an additional average of 8.1 days/year. Thus, the total average downtime is estimated to be 23.1 days/year. Given the simulated yields based on 50 years of historical weather, expected biomass yield on the land selected by model 1 for leasing and seeding to switchgrass in year zero would exceed 700,000 Mg in 22 of the 50 years. In these 22 years, biomass production would be sufficient to provide 2,000 Mg for each of the assumed 350 working days. Excess production is assumed to be mowed and left on the soil surface to decompose. However, in 28 of the 50 years, biomass production on the 73,856 ha leased would not be sufficient. Thus, on average, based on the parameter levels, it is not economically optimal to lease sufficient land to insure that biomass production in each year is sufficient to prevent shut downs beyond those required for maintenance. 
For a biofuel price of $\$ 0.50 / \mathrm{L}$, if Class I-IV land may be used, 52,034 ha would be optimally leased to produce an average feedstock quantity of $691,971 \mathrm{Mg} / \mathrm{year}$. If land use is unrestricted, the average biorefinery downtime is 4.0 days/year. If 52,034 ha are leased, it costs $\$ 58$ to produce and transport one $\mathrm{Mg}$ of feedstock to the processing plant and the expected net returns are estimated at $\$ 13.62 \mathrm{M} / \mathrm{year}$ (Table 1).

When land use is restricted to Classes III and IV, for a biofuel price of $\$ 0.50 / \mathrm{L}, 59,084$ ha (Table 1) would be optimally leased. Most of the land leased is Class III with Class IV used in the county where the biorefinery is located taking advantage of the shorter field to biorefinery transportation distances. The land requirement is $14 \%$ greater than the quantity of land optimally leased when land from Classes I-IV can be leased. The average annual quantity of feedstock delivered is $691,858 \mathrm{Mg}$. This results in an average 4.1 days/year of plant downtime (Table 1).

The results from model 1 are used to calculate the biorefinery investment payback period and the rate of return on invested capital, for each of the three land availability scenarios, using the expected annual net returns at each biofuel price. The payback period is the length of time required to recover the total initial investment cost, calculated as the ratio of the initial investment to the annual expected net cash flow of the project. The project net cash flow is estimated using the expected annual after tax net returns. The total initial investment cost includes the biorefinery investment cost, the investment in harvest machines, the investment in transportation trucks, and the switchgrass establishment cost. The biorefinery investment cost is estimated at $\$ 220 \mathrm{M}$ (USA EPA, 2010), the investment in harvest machines is estimated at $\$ 30$ M (Haque and Epplin, 2012). The number of trucks necessary to transport 2,000 Mg/day from the field to the biorefinery in each operating day is a function of the average hauling distance, which depends on the location of the land leased. The optimal number of trucks is calculated 
following Wang (2009) and Kumar and Sokhansanj (2009) using the average transportation distance in each land use scenario. The purchase price of a class eight truck with day cab and a $16 \mathrm{~m}$ flatbed trailer is budgeted at $\$ 146,012$ (USA EPA, 2010). Depending on the biofuel price and the land use assumption, the estimated number of trucks necessary to transport 2,000 Mg/day ranges from 13 to 31 .

Because the quantity of land optimally leased increases as land use is restricted, the switchgrass establishment cost as well as the average transportation distance and the number of trucks that would be required to haul the feedstock from field to the biorefinery vary across land use scenarios. As a consequence, for a given level of biofuel price, the biorefinery investment payback period increases and the project's rate of return on investment decreases as land use is restricted (Table 2). At lower ethanol prices $(\$ 0.50 / \mathrm{L}$ or less), the 20 -year projected biorefinery project life, would not be long enough for the biorefinery to breakeven, even if land use is unrestricted. For an ethanol price at $\$ 0.50 / \mathrm{L}$ which is equivalent to an expected crude oil price of $\$ 80 /$ barrel, the investment payback period is 172 years if only land of Class IV could be leased and the expected rate of return on investment is $1 \%$ per year (Table 2). If land of Classes III and IV could be leased, the payback period is 42 years and the investment expected annual rate of return is $2 \%$ per year. When land use is unrestricted the project's payback period is 34 years with a 3\% annual rate of return on investment (Table 2). For a biofuel price at $\$ 1.00 / \mathrm{L}$ the investment payback period is 3-4 years and the investment rate of return ranges from 25 to $30 \%$ (Table 2). These results suggest that with the USA Energy Information Administration's (EIA, 2015A) crude oil price projections between $\$ 81$ and $\$ 141 /$ barrel for the period 2022 - 2040, it would be difficult for the biorefinery investment as modeled for the region to result in a payback period of less than 20 years. 


\subsection{Model 2: Optimal land lease with interyear storage}

Model 2 is solved to identify the tradeoff between leasing enough land, storing biomass from year-to-year, and allowing some biorefinery downtime days in some years. The model is solved for a biofuel price at $\$ 0.75 / \mathrm{L}$ ( $\$ 131 /$ barrel), for three levels of estimated interyear storage cost and storage loss estimated to be $15 \% / y e a r$. If land lease is restricted to land Class IV, it is optimal to allow some downtime for the three levels of storage cost considered (Table 3). For the scenarios with land Classes III and IV, and Classes I-IV, model 2 selects enough land such that biomass produced when supplemented with interyear storage is sufficient to meet the biorefinery processing capacity in every year (Table 3 ).

If land use is restricted to Class IV, for a storage cost of $\$ 6 / \mathrm{Mg}, 76,786$ ha are optimally leased and the average annual quantity of biomass delivered is $699,839 \mathrm{Mg}$. The expected annual net returns are estimated at $\$ 66.9 \mathrm{M}$. If the storage cost is $\$ 12 / \mathrm{Mg}, 77,209$ ha are optimally leased and the quantity of feedstock produced is $699,503 \mathrm{Mg}$. The annual expected net returns are estimated at $\$ 66.6 \mathrm{M}$. For the storage cost of $\$ 18 / \mathrm{Mg}, 77,192$ ha are optimally leased to deliver an average 698,949 Mg/year (Table 3). The expected net returns are \$66.4 M.

If land use is restricted to Classes III and IV, the quantity of land optimally leased is on average $27 \%$ less than that of the land leased when land use is restricted to Class IV (Table 3). For interyear storage cost of $\$ 6 / \mathrm{Mg}$, it is optimal to lease 55,743 ha and deliver the $700,000 \mathrm{Mg}$ of feedstock required by the biorefinery in every year. The expected annual net returns increase by $15 \%$ relative to when land use is restricted to Class IV. The quantity of land optimally leased is insensitive to the cost of interyear storage (Table 3).

If land use is unrestricted such that Classes I-IV can be leased, for storage cost of $\$ 6 / \mathrm{Mg} /$ year, 51,420 ha are optimally leased to deliver the annual 700,000 $\mathrm{Mg}$ of feedstock 
required by the biorefinery. The optimal land leased is 52,015 and 52,436 ha for storage costs of $\$ 12$ and $\$ 18 / \mathrm{Mg}$, respectively. The expected annual net returns are estimated at $\$ 79.5 \mathrm{M}$ and $\$ 79.4 \mathrm{M}$ for storage cost of $\$ 12$ and $\$ 18 / \mathrm{Mg}$, respectively (Table 3).

The total annual feedstock trucking distance from the field to the processing plant more than doubles when land use is restricted to Class IV compared to when land use is unrestricted (Table 3). For a storage cost of $\$ 6 / \mathrm{Mg} /$ year, the transportation distance increases from $2.6 \mathrm{M}$ $\mathrm{km} /$ year to $5.8 \mathrm{M} \mathrm{km} /$ year (223\% greater) when land use is restricted to Class IV. If the storage cost is $\$ 18 \mathrm{Mg} /$ year, the trucking distance decreases from $5.8 \mathrm{M} \mathrm{km} /$ year when land use is restricted to Class IV, to $2.7 \mathrm{M} \mathrm{km} /$ year when land use is unrestricted (Table 3). The difference in the total travel distances across land use scenarios are nearly the same with model 1 as with model 2.

\section{Discussion and Conclusion}

The production of switchgrass on USA marginal land has been proposed as a way to produce something of value on millions of policy-idled hectares. Due diligence would require that potential biorefinery investors be provided a business plan for providing a flow of switchgrass biomass for the expected life of the biorefinery. To achieve cost economies a biorefinery may require production from thousands of hectares, and long-term lease contracts with hundreds of private landowners.

Conceptually, the land area selected, leased, and seeded to switchgrass, would be determined and fixed in year zero, simultaneous with construction of the biorefinery. In year one and subsequent years, biomass production on the fixed land area would vary depending on soil characteristics and environmental conditions. Given the expected yield and variability across years, determining the optimal quantity of land to bid from current use and convert to 
switchgrass is not a trivial matter. Failure to provide feedstock would result in costly disruptions of biorefinery operations.

The present study determines the optimal land leased for an assumed biorefinery capacity, for a strategy that allows downtime days in those years when it is economical to do so, and a strategy that incorporates a storage capacity for three land availability scenarios when: (a) land use is restricted to Class IV; (b) land use is restricted to Classes III and IV; and (c) land use is unrestricted. The study finds that restricting switchgrass production to less productive marginal land increases the land requirement, increases total biomass transportation distance, increases investment payback period, and reduces profitability. Ultimately, the specific land converted from existing use to the production of a dedicated energy crop, will be determined by land owners and biomass businesses. Therefore, in the absence of government restrictions, it is unlikely that land use would be limited to marginal land. Public policies that impose restrictions on the type of land that may be converted from current use for energy crop production would increase biofuel production cost and reduce the likelihood of cellulosic biorefineries being built.

The modeling approach presents two main advantages. First, the model includes a strategy that enables idling the biorefinery in years of insufficient feedstock production due to switchgrass yield variability if it is economically optimal to do so. Second, the model endogenously integrates the penalty cost that would be incurred, when the processing plant is idled, due to insufficient feedstock. The approach captures the relative difference between the marginal cost of idling the processing plant and the marginal cost of leasing an additional unit of land to produce feedstock and avoid idling the plant. Also, even though the results are presented for a case study region, the model is applicable to other regions. 
Acknowledgements: The authors acknowledge the assistance of resources provided by the Oklahoma Agricultural Experiment Station. Additional funding was provided by the USDANIFA, USDA-DOE Biomass Research and Development Initiative, Grant No. 2009-1000606070. The project was also supported by the USDA National Institute of Food and Agriculture, Hatch grant number H-2824, and by the Jean \& Patsy Neustadt Chair. Support does not constitute an endorsement of the views expressed in the paper by the USDA. 


\section{References}

Bhardwaj, A, T, Z., Jasrotia P., Robertson, G., Chen, J., Hamilton, S., 2011. Water and energy footprints of bioenergy crop production on marginal lands. GCB Bioenergy, 3:208-22.

Caldas, M.M., Bergtold, J.S., Peterson, J.M., Graves, R., Earhart, D., Gong, S., Lauer, B., Brown, J.C., 2014. Factors affecting famers' willingness to grow alternative biofuel feedstocks across Kansas. Biomass and Bioenergy 66: 223 - 231.

Cundiff, J. S., Marsh, L. S., 1996. Harvest and storage costs for bales of switchgrass in the southeastern United States. Bioresource Technolology, 56:95-101.

Dauber, J., Brown, C., Fernando, A.L., Finnan, J., Krasuska, E., Ponitka, J., Styles, D., Thrän, D., Groenigen, K.J.V., Weih, M., Zah, R., 2012. Bioenergy from “surplus” land: Environmental and socio-economic implications. BioRisk, 7:5-50

Debnath, D., Epplin, F.M., Stoecker, A.L., 2014. Managing spatial and temporal switchgrass biomass yield variability. BioEnergy Research, 7:946-57.

Debnath, D., Epplin, F.M., Stoecker, A.L., 2015. Switchgrass procurement strategies for managing yield variability: Estimating the cost-efficient D (Downtime cost) L (Land to Lease) frontier. Biomass and Bioenergy, 77:110-22.

Djomo, S.N., Witters, N., Van Dael, M., Gabrielle, B., Ceulemans, R., 2015. Impact of feedstock, land use change, and soil organic carbon on energy and greenhouse gas performance of biomass cogeneration technologies. Applied Energy, 154:122-30.

Dodder, R.S., Kaplan, P.O., Elobeid, A., Tokgoz, S., Secchi, S.,. Kurkalova L.A., 2015. Impact of energy prices and cellulosic biomass supply on agriculture, energy, and the environment: An integrated modeling approach. Energy Economics 51 77-87. 
Egbendewe-Mondzozo A, Swinton, S.M., Izaurralde, C.R., Manowitz, D.H., Zhang X., 2011. Biomass supply from alternative cellulosic crops and crop residues: A spatially explicit bioeconomic modeling approach. Biomass Bioenergy, 35:4636-4647.

Epplin, F.M., Clark, C.D., Roberts, R.K., Hwang. S., 2007. Challenges to the development of a dedicated energy crop. American Journal of Agricultural Economics, 89:1296-1302.

Fuentes, R.G., Taliaferro, C.M., 2002. Biomass yield stability of switchgrass cultivars. In: J. Janick and A. Whipkey ed. Trends in New Crops and New Uses. Alexandria. VA: ASHS Press, 276-282.

Gelfand, I., Sahajpal, R., Zhang X., Izaurralde R.C., Gross K.L., Robertson G.P., 2013. Sustainable bioenergy production from marginal lands in the U.S. Midwest. Nature, 493:514-517.

Griffith, A.P., Haque, M., Epplin, F.M., 2014. Cost to produce and deliver cellulosic feedstock to a biorefinery: Switchgrass and forage sorghum. Applied Energy, 127:44-54.

Haque, M., Epplin, F.M., 2012. Cost to produce switchgrass and cost to produce ethanol from switchgrass for several levels of biorefinery investment cost and biomass to ethanol conversion rates. Biomass Bioenergy, 46:517-530.

Haque, M., Epplin, F.M., Taliaferro, C.M., 2009. Nitrogen and harvest frequency effect on yield and cost for four perennial grasses. Agronomy Journal, 101:1463-1469.

Haque, M., Epplin, F.M., Biermacher, J.T., Holcomb, R., Kenkel,P., 2014. Marginal cost of delivering switchgrass feedstock and producing cellulosic ethanol at multiple biorefineries. Biomass and Bioenergy 66:308-319. 
Jensen, K., Clark, C.D., Ellis, P., English, B., Menard, J., Walsh, M., de la Torre Ugarte, D., 2007. Farmer willingness to grow switchgrass for energy production. Biomass and Bioenergy 31:773-781.

Jensen, K., Clark, C.D., English, B.C., Menard, R.J., 2011. Preferences for marketing arrangements by potential switchgrass growers. Journal of Cooperatives 25(2):16-43.

Katz, J. P., Boland, M.A., 2002. One for all and all for one? A new generation of cooperatives emerges. Long Range Planning, 35:73-89.

Kumar, A., Sokhansanj, S., 2007. Switchgrass (Panicum vigratum, L.) Delivery to a Biorefinery using integrated biomass supply analysis and logistics (IBSAL) model. Bioresource Technolology, 98:1033-1044.

Larson, J.A., Yu T.H., English, B.C., Mooney, D.F., Wang, C., 2010. Cost evaluation of alternative switchgrass producing, harvesting, storing, and transporting systems and their logistics in the southeastern usa. Agricultural Finance Review, 70:184-200.

Leal, M.R. L, Nogueira, L.A.H., Cortez, L.A., 2013. Land demand for ethanol production. Applied Energy, 102:266-71.

Liu, T.T., McConkey, B.G., Ma, Z.Y., Liu, Z.G., Li X., Cheng, L. L., 2011. Strengths, weaknessness, opportunities and threats analysis of bioenergy production on marginal land. Energy Procedia, 5:2378-2386.

McLaughlin, S., Bouton, J., Bransby, D., Conger, B., Ocumpaugh, W., Parrish, D., Taliaferro, C., Vogel, K., Wullschleger, S., 1999. Developing switchgrass as a bioenergy crop. In J. Janick, ed. Perspectives on New Crops and New Uses. ASHS Press, Alexandria, pp. 282299. 
National Oceanic and Atmospheric Administration, 2014. Daily Weather Data for Oklahoma. http://gis.ncdc.noaa.gov/map/viewer/\#app=clim\&cfg=cdo\&theme=daily\&layers=0001\&no de=gis 2014. Accessed August 16, 2014.

Norton, E.A., 1939. Soil Conservation Survey Handbook . U.S. Department of Agriculture; Oklahoma Climatological Survey. Oklahoma Mesonet. 2014. Daily Weather Data. http://cig.mesonet.org/ gmcmanus/freeze/freeze.html/; Accessed August 16, 2014.

Okwo A., Thomas V.M., 2014. Biomass feedstock contracts: Role of land quality and yield variability in near term feasibility. Energy Economics, 42:67-80.

Osborn, C.T., Llacuna, F., Linsenbigler. M., 1995. The Conservation Reserve Program: Enrollment Statistics for Signup Periods 1-12 and Fiscal Years 1986-93. Washington, D.C.: Economic Research Service, U.S. Department of Agriculture, Natural Resources and Environment Division; November 102 p. Statistical Bulletin No. 925.

Perlack, R.D., Wright, L.L., Turhollow, A.F., Graham, R.L., Stokes, B.J., Erbach, D.C., 2005. Biomass as Feedstock for a Bioenergy and Bioproducts Industry: The Technical Feasibility of a Billion-Ton Annual Supply. Oak Ridge National Laboratory Tennessee.

Richards, B.K., Stoof, C.R., Cary, I.J., Woodbury, P.B., 2014. Reporting on Marginal Lands for Bioenergy Feedstock Production: A Modest Proposal. BioEnergy Research, 7:1060-1062.

Sanderson, M.A., Egg, R. P. Wiselogel, A.E., 1997. Biomass losses during harvest and storage of switchgrass. Biomass and Bioenergy, 12:107-114.

Searchinger, T., Heimlich, R., Houghton, R.A., Dong, F., Elobeid, A., Fabiosa, J., Tokgoz, S., Hayes, D., Yu, T., 2008. Use of U.S. croplands for biofuels increases greenhouse gases through emissions from land-use change. Science, 319:1238-1240. 
Skevas, T., Hayden, N.J., Swinton, S.M., Lupi, F., 2016. Landowner willingness to supply marginal land for bioenergy production. Land Use Policy 50:507-517.

Turhollow, A.F.Jr., Webb, E., Sokhansanj, S., 2009. Cost methodology for biomass feedstocks: Herbaceous crops and agricultural residues. Oak Ridge National Laboratory (ORNL). Turhollow, A.F., Epplin, F.M., 2010. Estimating region specific costs to produce and deliver switchgrass. Switchgrass: A Valuable Biomass Crop for Energy. ed. Andrea Monti. Chapter 8. New York: Springer Publishing Co.

United States Department of Agriculture, Economic Research Service, 2015. Commodity costs and returns. http://www.ers.usda.gov/data-products/commodity-costs-and-returns.aspx. Accessed March 18, 2015.

United States Department of Agriculture, Farm Service Agency, 2014. Conservation Programs. http://www.fsa.usda.gov/FSA/webapp?area=home\&subject=copr\&topic=rns-css. Accessed December 18, 2014.

United States Department of Agriculture, Soil Service Geographic (SSURGO), 2014. Database for Oklahoma. http://websoilsurvey.sc.egov.usda.gov/App/HomePage.htm/.Accessed August 8, 2014.

United States Energy Information Administration, 2015A. Current issues \& trends. http://www.eia.gov/analysis/. Accessed March 31, 2015.

United States Energy Information Administration, 2015B. Petroleum and other liquids outlook. http://www.eia.gov/dnav/pet/hist/LeafHandler.ashx?n=pet\&s=emd_epd2d_pte_nus_dpg\&f =a, 2015. Accessed March 4, 2015.

United States Environmental Protection Agency, 2010 . Renewable fuel standard program (RFS2) regulatory impact analysis. 
http://www.epa.gov/otaq/renewablefuels/420r10006.pdf. Accessed March 14, 2014.

Wang, C., 2009. Economic analysis of delivering switchgrass to a biorefinery from both the farmers' and processor's perspectives. MS thesis University of Tennessee, Knoxville.

Williams, J.R., Jones, C.A., Dyke, P.T., 1984. Modeling approach to determining the relationship between erosion and soil productivity. Transactions of the American Society of Agricultural Engineers 129-144.

Winchester, N., Reilly, J.M., 2015. The feasibility, costs, and environmental implications of large-scale biomass energy. Energy Economics. doi:10.1016/j.eneco.2015.06.016

Winchester, N., Robert Malin, R., Staples, M., S. R.H. Barrett. 2015. The impact of advanced biofuels on aviation emissions and operations in the US. Energy Economics, 49: 482-491.

Wise M., Dooley J., Luckow P., Calvin K., Kyle P., 2014. Agriculture, land use, energy and carbon emission impacts of global biofuel mandates to Mid-Century. Applied Energy, 114:763-73.

Wise, M., Hodson, E.L., Mignone, B.K., Clarke, L., Waldhoff, S., Luckow, P., 2015. An approach to computing marginal land use change carbon intensities for bioenergy in policy applications. Energy Economics, 47: 307-318.

Zhang, J., Osmani, A., Awudu, I., Gonela, V., 2013. An integrated optimization model for switchgrass-based bioethanol supply chain. Applied Energy 102:1205-1217. 
Table 1. Expected annual net revenue, average number of days of biorefinery downtime per year, average feedstock cost, optimal quantity of land to lease, and total trucking distances for three land use and three biofuel price scenarios.

\begin{tabular}{|c|c|c|c|c|c|c|c|c|c|c|}
\hline $\begin{array}{l}\text { Land Classes } \\
\text { permitted }\end{array}$ & $\begin{array}{c}\text { Biofuel } \\
\text { price } \\
(\$ / L)\end{array}$ & $\begin{array}{l}\text { Crude oil } \\
\text { price } \\
(\$ / \text { barrel })^{\mathrm{a}}\end{array}$ & $\begin{array}{l}\text { Expected } \\
\text { net } \\
\text { revenue } \\
\text { (M \$/year) }\end{array}$ & $\begin{array}{l}\text { Land } \\
\text { leased } \\
\text { (ha) }\end{array}$ & $\begin{array}{l}\text { Class IV } \\
\text { land } \\
\text { leased }^{\mathrm{b}} \\
\text { (ha) }\end{array}$ & $\begin{array}{l}\text { Average } \\
\text { annual } \\
\text { feedstock } \\
\text { delivered } \\
(\mathrm{Mg}) \\
\end{array}$ & $\begin{array}{l}\text { Average } \\
\text { annual } \\
\text { feedstock } \\
\text { shortage } \\
(\mathrm{Mg}) \\
\end{array}$ & $\begin{array}{c}\text { Average } \\
\text { annual } \\
\text { downtime } \\
\text { (days/year) }\end{array}$ & $\begin{array}{c}\text { Total biomass } \\
\text { trucking } \\
\text { distance } \\
(000 \\
\text { km/year })^{\mathrm{c}} \\
\end{array}$ & $\begin{array}{l}\text { Feedstock } \\
\text { delivered } \\
\text { cost }^{\mathrm{d}} \\
(\$ / \mathrm{Mg})\end{array}$ \\
\hline Class IV & & & 2.80 & 73,856 & 73,856 & 683,797 & 16,203 & 8.1 & 5,842 & 73 \\
\hline Class III \& IV & 0.50 & 80 & 11.03 & 59,084 & 4,049 & 691,858 & 8,142 & 4.1 & 3,739 & 62 \\
\hline Class I, II, III, \& IV & & & 13.62 & 52,034 & 4,049 & 691,971 & 8,029 & 4.0 & 2,723 & 58 \\
\hline Class IV & & & 64.80 & 80,605 & 80,605 & 693,698 & 6,302 & 3.2 & 5,832 & 80 \\
\hline Class III \& IV & 0.75 & 131 & 74.59 & 60,099 & 4,049 & 695,586 & 4,414 & 2.2 & 3,865 & 66 \\
\hline Class I, II, III, \& IV & & & 78.07 & 54,920 & 4,049 & 697,708 & 2,292 & 1.1 & 2,702 & 62 \\
\hline Class IV & & & 126.55 & 84,252 & 84,252 & 696,408 & 3,592 & 1.8 & 5,752 & 86 \\
\hline Class III \& IV & 1.00 & 182 & 137.76 & 63,612 & 6,890 & 697,143 & 2,857 & 1.4 & 3,670 & 70 \\
\hline Class I, II, III, \& IV & & & 142.03 & 55,519 & 4,049 & 698,175 & 1,825 & 0.9 & 2,681 & 64 \\
\hline
\end{tabular}

${ }^{a}$ The crude oil price is determined based on a linear regression (OLS) of the annual price of gasoline (1995-2013) on the annual crude oil price (1995- 2013) (EIA, 2015,B).

${ }^{b}$ For the case study region, $6 \%$ of the total land (713,716 ha) is Class I, $23 \%$ is Class II, $48 \%$ is Class III and $23 \%$ is Class IV.

${ }^{\mathrm{c}}$ The transportation distance is calculated assuming that a truck can haul $16 \mathrm{Mg}$ per load, and each load necessitates a roundtrip.

${ }^{\mathrm{d}}$ The delivered feedstock cost includes the field production cost and the transportation cost. 
Table 2. Total investment requirement, expected annual net returns and payback period of the biorefinery investment for three levels of biofuel price and three land use scenarios.

\begin{tabular}{|c|c|c|c|c|c|c|c|c|}
\hline $\begin{array}{l}\text { Land Classes } \\
\text { permitted }\end{array}$ & $\begin{array}{l}\text { Biofuel } \\
\text { price } \\
(\$ / L)\end{array}$ & $\begin{array}{l}\text { Crude oil } \\
\text { price } \\
(\$ / \text { barrel })^{\mathrm{a}}\end{array}$ & $\begin{array}{l}\text { Expected net } \\
\text { revenue } \\
\text { (M \$/year) }\end{array}$ & $\begin{array}{l}\text { Estimated taxes } \\
\text { (M \$/year) }\end{array}$ & $\begin{array}{l}\text { Expected net } \\
\text { revenue after tax } \\
\text { (M \$/year) }\end{array}$ & $\begin{array}{l}\text { Assumed } \\
\text { Total } \\
\text { investment }^{\mathrm{c}} \\
(\mathrm{M} \$)\end{array}$ & $\begin{array}{c}\text { Expected } \\
\text { annual rate of } \\
\text { return on } \\
\text { invested capital } \\
(\%)\end{array}$ & $\begin{array}{l}\text { Payback } \\
\text { period }^{\mathrm{d}} \\
\text { (years) }\end{array}$ \\
\hline Class IV & & & 2.80 & 1.12 & 1.68 & 288.6 & $1 \%$ & 172 \\
\hline Class III \& IV & 0.50 & 80 & 11.03 & 4.42 & 6.61 & 280.7 & $2 \%$ & 42 \\
\hline Class I, II, III, \& IV & & & 13.62 & 5.48 & 8.14 & 277.7 & $3 \%$ & 34 \\
\hline Class IV & & & 64.80 & 26.57 & 38.23 & 291.1 & $13 \%$ & 8 \\
\hline Class III \& IV & 0.75 & 131 & 74.59 & 30.58 & 44.01 & 281.0 & $16 \%$ & 6 \\
\hline Class I, II, III, \& IV & & & 78.07 & 32.01 & 46.06 & 279.5 & $16 \%$ & 6 \\
\hline Class IV & & & 126.55 & 51.89 & 74.66 & 294.1 & $25 \%$ & 4 \\
\hline Class III \& IV & 1.00 & 182 & 137.76 & 56.48 & 81.28 & 281.9 & $29 \%$ & 3 \\
\hline Class I, II, III, \& IV & & & 142.03 & 58.23 & 83.80 & 280.3 & $30 \%$ & 3 \\
\hline
\end{tabular}

${ }^{a}$ The crude oil price is determined based on a linear regression (OLS) of the annual price of gasoline (1995-2013) on the annual crude oil price (1995- 2013) (EIA, 2015, B).

${ }^{\mathrm{b}}$ The estimated taxes are calculated using the federal and the Oklahoma state corporate income tax rates. The federal corporate income tax rate varies with the level of taxable income while the Oklahoma corporate tax rate is flat at $6 \%$.

${ }^{\mathrm{c}}$ The total investment cost includes the initial biorefinery investment for a plant with a processing capacity of $262.5 \mathrm{M} \mathrm{L/year,} \mathrm{the}$ investment in harvest machines, the investment in transportation trucks, and the switchgrass establishment cost.

${ }^{d}$ The payback period is the length of time required to recover the total initial investment cost with the corresponding expected annual net returns. 
Table 3. Optimal land leased, feedstock storage and shortage, and feedstock cost for three land use scenarios and three levels of storage cost $t^{\mathrm{a}}$.

\begin{tabular}{|c|c|c|c|c|c|c|c|c|}
\hline $\begin{array}{l}\text { Land Classes } \\
\text { permitted }\end{array}$ & $\begin{array}{l}\text { Storage cost } \\
\quad(\$ / \mathrm{Mg})\end{array}$ & $\begin{array}{l}\text { Expected } \\
\text { net revenue } \\
\text { (M \$/year) }\end{array}$ & $\begin{array}{l}\text { Land leased } \\
\text { (ha) }\end{array}$ & $\begin{array}{l}\text { Average } \\
\text { annual } \\
\text { feedstock } \\
\text { shortage } \\
\text { (Mg) }\end{array}$ & $\begin{array}{l}\text { Average } \\
\text { annual } \\
\text { feedstock } \\
\text { delivered } \\
\quad(\mathrm{Mg})\end{array}$ & $\begin{array}{l}\text { Average annual } \\
\text { feedstock stored } \\
\qquad(\mathrm{Mg})\end{array}$ & $\begin{array}{l}\text { Total biomass } \\
\text { trucking distance } \\
(000 \mathrm{~km} / \text { year })^{\mathrm{b}}\end{array}$ & $\begin{array}{c}\text { Delivered } \\
\text { feedstock } \\
\text { cost } \\
(\$ / \mathrm{Mg})\end{array}$ \\
\hline Class IV & \multirow{2}{*}{6} & 66.9 & 76,786 & 161 & 699,839 & 52,289 & 5,845 & 78 \\
\hline Class III \& IV & & 76.9 & 55,743 & 0 & 700,000 & 31,347 & 3,786 & 64 \\
\hline Class IV & \multirow{3}{*}{12} & 66.6 & 77,209 & 497 & 699,503 & 41,290 & 5,837 & 78 \\
\hline Class III \& IV & & 76.7 & 55,926 & 0 & 700000 & 28,419 & 3,783 & 64 \\
\hline Class I, II, III, \& IV & & 79.5 & 52,015 & 0 & 700,000 & 20,977 & 2,639 & 60 \\
\hline Class IV & 18 & 66.4 & 77,192 & 1,051 & 698,949 & 35,256 & 5,814 & 79 \\
\hline
\end{tabular}

${ }^{\mathrm{a}} \mathrm{A}$ biofuel price at $\$ 0.75 / \mathrm{L}$ (\$131/barrel) is assumed to solve model 2 for different storage costs and $15 \%$ annual dry matter storage loss.

${ }^{\mathrm{b}}$ The transportation distance is calculated assuming that a truck can haul $16 \mathrm{Mg}$ per load, and each load necessitates a roundtrip 


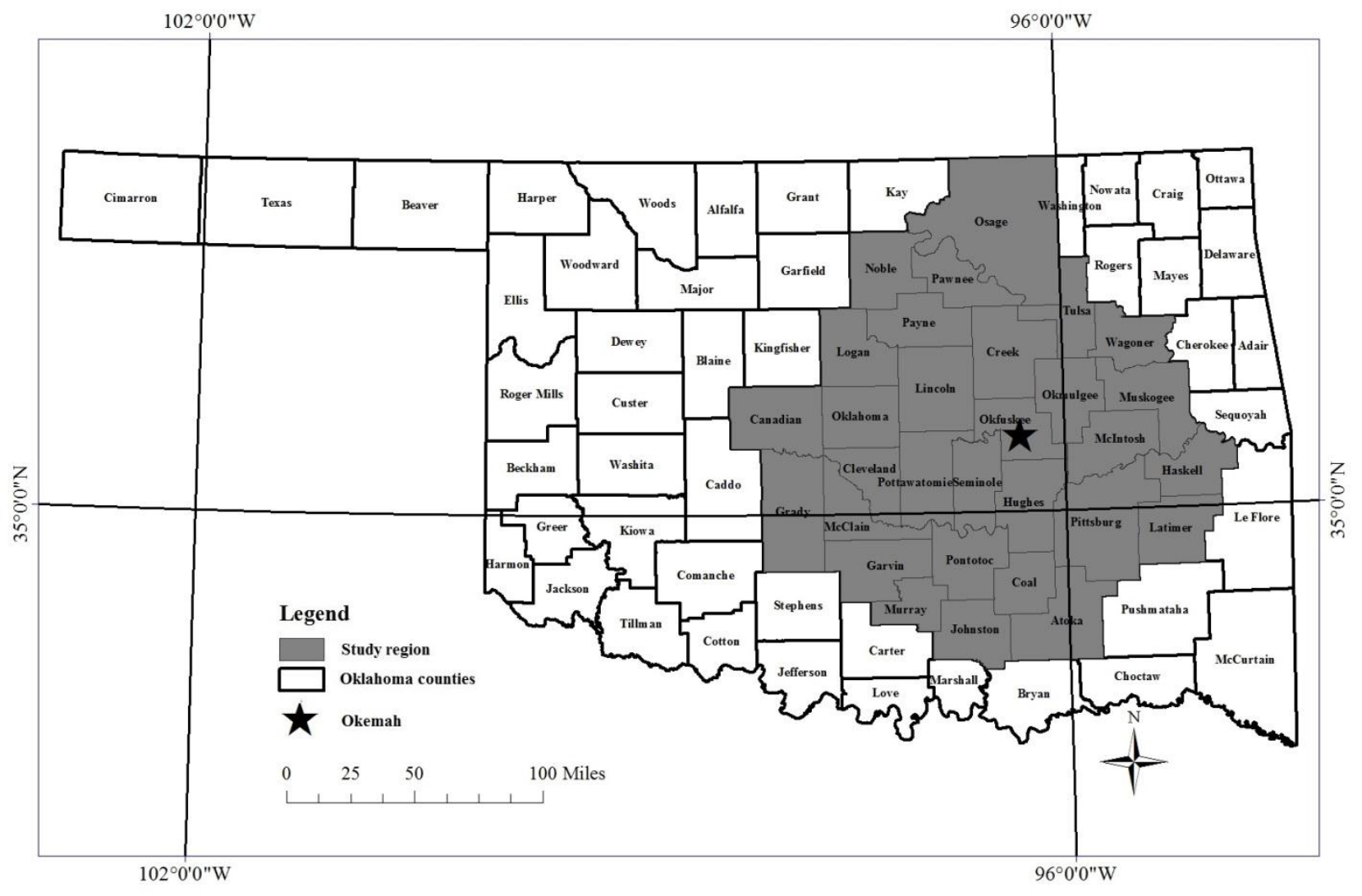

Figure 1. Delimited Study Region of 30 Counties in Central Oklahoma. 